\title{
New record of Pelecitus sp. (Nematoda, Onchocercidae) as a parasite of Athene cunicularia (Strigiformes, Strigidae) in southeastern Brazil
}

\author{
Novo registro de Pelecitus sp. (Nematoda, Onchocercidae) como parasita de Athene cunicularia \\ (Strigiformes, Strigidae) no Sudeste do Brasil \\ Tarcísio Macedo Silva ${ }^{1}$; Adriano Sakai Okamoto ${ }^{1 *}$; Lidiane Aparecida Firmino da Silva ${ }^{2}$; \\ Bruna Domeneghetti Smaniotto ${ }^{1}$; Reinaldo José da Silva²; Raphael Lucio Andreatti Filho

\begin{abstract}
${ }^{1}$ Departamento de Clínica Veterinária, Laboratório de Ornitopatologia, Faculdade de Medicina Veterinária e Zootecnia, Universidade Estadual Paulista "Júlio de Mesquita Filho" - UNESP, Botucatu, SP, Brasil

${ }^{2}$ Departamento de Parasitologia, Instituto de Biociências, Universidade Estadual Paulista “Júlio de Mesquita Filho” - UNESP,

Botucatu, SP, Brasil
\end{abstract}

Received November 15, 2013

Accepted April 2, 2014

\begin{abstract}
The aim of this study was to report the burrowing owl Athene cunicularia as a new host for the filarid nematode Pelecitus sp. in southeastern Brazil for the first time, as well as reporting the occurrence of this nematode species in the body cavity, near the cervical air sac and lung region. This study contributes towards knowledge of parasitism in Brazilian wild birds and an anatomical region of the host as an infection site for Pelecitus sp.
\end{abstract}

Keywords: Parasitic nematodes, Pelecitus sp., birds, Strigiformes, Athene cunicularia.

\section{Resumo}

O objetivo do estudo foi relatar, pela primeira vez, a coruja buraqueira Athene cunicularia como um novo hospedeiro para o nematóide filarídeo Pelecitus sp. do Sudeste do Brasil, bem como a ocorrência desta espécie de nematóides na cavidade corporal, próximos à regiáo dos sacos aéreos cervicais e pulmôes. Este estudo contribui para o conhecimento do parasitismo em aves silvestres brasileiras e uma região anatômica do hospedeiro como sítio de infecção para Pelecitus sp.

Palavras chave: Nematóides parasitas, Pelecitus sp., aves, Strigiformes, Athene cunicularia.

Athene cunicularia, or the burrowing owl, is a small raptor bird that is indigenous to all of the Americas and widely distributed throughout Brazilian territory (SICK, 2001). These birds inhabit both rural and urban ecosystems (CONWAY et al., 2006) and are considered to have diurnal habits, though also demonstrating nocturnal activities (SPECHT et al., 2013). Their diet includes a vast array of invertebrates (insects and chelicerates) and vertebrates (amphibians, reptiles, birds and mammals), varying according to season and habitat (ANDRADE et al., 2010; TRULIO; HIGGINS, 2012).

The parasitic infections caused by nematodes that affect the respiratory system of domestic and wild birds include parasitism by Syngamus trachea and Cyathostoma bronchiali (FERNANDO;

\footnotetext{
*Corresponding author: Adriano Sakai Okamoto

Laboratório de Ornitopatologia, Departamento de Clínica Veterinária,

Faculdade de Medicina Veterinária e Zootecnia, Universidade Estadual Paulista "Júlio de Mesquita Filho" - UNESP, Distrito de Rubião Júnior, CP 560, CEP 18618-970, Botucatu, SP, Brasil

e-mail: sakai@fmvz.unesp.br
}

BARTA, 2009). Filarid nematodes belonging to the genera Eulimdana and Pelecitus have been reported to infect the respiratory system in pigeons (Columba livia) (RUTHERFORD; BLACK, 1974).

Nematodes of the family Onchocercidae are parasites of vertebrates and are grouped into 16 genera. The genus Pelecitus has 160 species that infect mammals and, especially, birds (BARTLETT, 2009). Three species of Pelecitus have been reported as infecting leporids, as follow: Pelecitus meridionaleporinus (JIMÉNEZ-RUIZ et al., 2004), Pelecitus scapiceps, and Pelecitus roemeri (BARTLETT; GREINER, 1986). The majority of Pelecitus spp. have been reported as infecting birds of 30 families (BARTLETT, 2009).

One dead specimen of $A$. cunicularia was collected by environmental authorities in the municipality of Botucatu $\left(22^{\circ} 51^{\prime} \mathrm{S}, 48^{\circ} 27^{\prime} \mathrm{W} ; 780 \mathrm{~m}\right)$, state of Sáo Paulo, Brazil, on July 15,2013 , and was forwarded for necropsy examination. During the necropsy, two nematodes were found in the specimen's body, near the cervical air sacs and lungs. They were fixed in $70 \%$ 


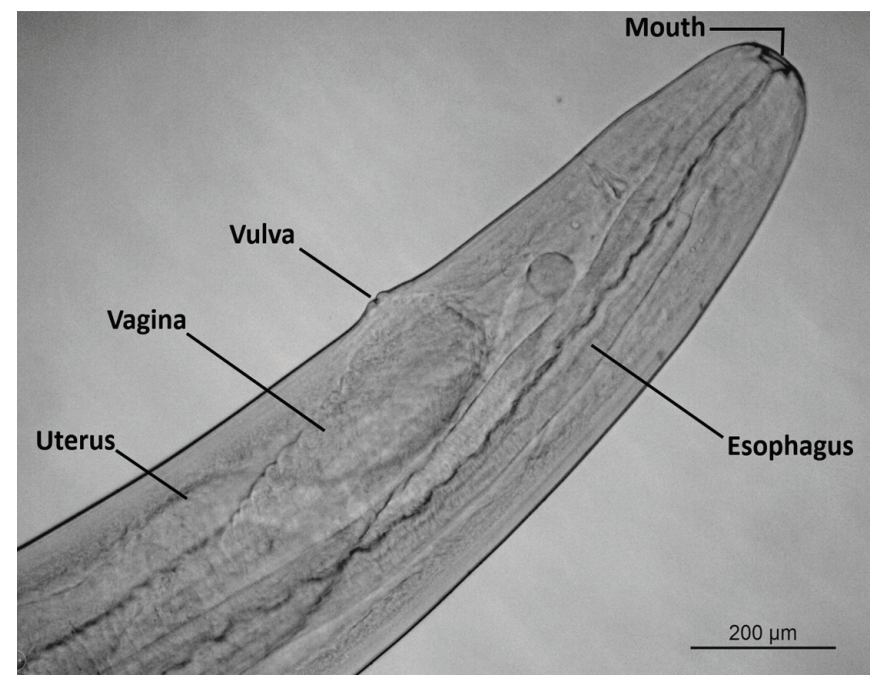

Figure 1. Anterior end of a female specimen of Pelecitus sp. collected from Athene cunicularia in the municipality of Botucatu, state of São Paulo, Brazil.

alcohol and clarified in phenol for identification, which was done using a computerized image analysis system (Leica). The nematodes collected were both females, and were in the genus Pelecitus (Figure 1), according to Vicente et al. (1995) and Pinto and Noronha (2003). Voucher parasite specimens were deposited in the helminthological collection of the Institute of Biosciences, São Paulo State University, Botucatu, São Paulo, Brazil, under the number CHIBB 7174.

Filarids of the genera Aproctella, Cardiofilaria, Splendidofilaria, Lemdana and Pelecitus have been reported in birds of the family Strigidae (BARTLETT, 2009). Among the strigid hosts, Pelecitus circularis has been found infecting Strix magellanica (= Bubo magellanicus) in Brazil (BARTLETT; GREINER, 1986). However, this bird species does not originate in Brazil (CBRO, 2011).

Infections in birds due to Pelecitus spp. affect the muscles, tendons and nodes of the lower limbs (PINTO; NORONHA, 2003). Presence of Pelecitus sp. microfilariae has been reported in the lungs of C. livia, and presence of adult individuals has been reported in peritracheal tissue (RUTHERFORD; BLACK, 1974). The history of infection by this parasite in the respiratory system of species not belonging to the order Strigiformes and the presence of the parasite in the lower limbs of the host bear a close relationship to the possible kinds of infection in the species described. According to Anderson and Bartlett (1994), when Pelecitus fulicaeatrae reaches reproductive senescence, it infects places that cause inflammation or threaten the life of the host.

The new knowledge about the internal presence of the nematode contradicts what was reported by Pinto and Noronha (2003) and Bartlett (2009) in other bird species. This brings up an important question that needs to be considered, i.e. whether this finding is a new location for parasitism, given that presence of the filarid Pelecitus sp. in the body cavity located near the cervical air sacs and lungs has not previously been described in strigiform birds.

The occurrence of Pelecitus sp. parasitizing A. cunicularia is the first report of this nematode in this species in Brazilian territory, as well as a new site of infection for this nematode parasite. These findings contribute towards knowledge about this species, regarding infection in this new host.

\section{References}

Anderson RC, Bartlett CM. Ephemerality and reproductive senescence in avian filarioids. Parasit Today 1994; 10(1): 33-35. http://dx.doi. org/10.1016/0169-4758(94)90356-5

Andrade A, Nabte J, Kun ME. Diet of the burrowing owl (Athene cunicularia) and its seasonal variation in Patagonian steppes: implications for biodiversity assessments in the Somuncurá Plateau Protected Area, Argentina. Stud Neotrop Fauna Environ 2010; 42(2): 101-110. http:// dx.doi.org/10.1080/01650521.2010.502010

Bartlett CM. Filarioid nematodes. In: Atkinson CT, Thomas NJ, Hunter DB. Parasitic diseases of wild birds. Iowa: Wiley-blackwell; 2009. p. 439462. http://dx.doi.org/10.1002/9780813804620.ch26

Bartlett CM, Greiner EC. A revision of Pelecitus Railliet \& Henry, 1910 (Filarioidea, Dirofilariinae) and evidence for the 'capture' by mammals of filarioids from birds. Bull Mus Nat Hist 1986; 8(1): 47-99.

Comitê Brasileiro de Registros Ornitológicos - CBRO. Listas das aves do Brasil. CBRO; 2011 [cited 2014 Fev 10]. Available from: http://www. cbro.org.br/CBRO/pdf/avesbrasil2011.pdf.

Conway CJ, Garcia V, Smith MD, Ellis LA, Whitney JL. Comparative demography of Burrowing Owls in agricultural and urban landscapes in southeastern Washington. J Field Ornithol 2006; 77(3): 280-290. http:// dx.doi.org/10.1111/j.1557-9263.2006.00054.x

Fernando MA, Barta JR. Tracheal worns. In: Atkinson CT, Thomas NJ, Hunter DB. Parasitic diseases of wild birds. Ames: Wiley-blackwell; 2009. p. 343-354. PMid:19299339 PMCid:PMC2674831. http://dx.doi. org/10.1002/9780813804620.ch19

Jiménez-Ruiz FA, Gardner SL, Cervantes FA, Lorenzo CA. A new species of Pelecitus (Filarioidea: Onchocercidae) from the endangered tehuantepec jackrabbit Lepus flavigularis. J Parasitol 2004; 90(4): 803807. PMid:15357073. http://dx.doi.org/10.1645/GE-213R1

Pinto RM, Noronha D. Analysis of brazilian species of Pelecitus Railliet \& Henry (Nematoda, Filarioidea) with the establishment of new records. Rev Bras Zool 2003; 20(2): 361-364. http://dx.doi.org/10.1590/S010181752003000200029

Rutherford DM, Black H. Pelecitus, a peritracheal nematode in the pigeon. New Zealand Vet J 1974; 22(8): 147. PMid:4531601. http:// dx.doi.org/10.1080/00480169.1974.34153

Sick H. Ornitologia brasileira. Rio de Janeiro: Nova Fronteira; 2001.

Specht GV, Gonçalves GL, Young RJ. Comportamento de caça da coruja buraqueira, Athene cunicularia (Molina, 1782) (Aves: Strigiformes) em ambiente urbano em Belo Horizonte, Minas Gerais, Brasil. Lundiana 2013; 11(1-2): 17-20.

Trulio LA, Higgins P. The diet of western burrowing owls in an urban landscape. West North Am Nat 2012; 72(3): 348-356. http://dx.doi. org/10.3398/064.072.0309

Vicente JJ, Rodrigues HO, Gomes DC, Pinto RM. Nematóides do Brasil. Parte IV: Nematóides de aves. Rev Bras Zool 1995; 12(S1): 1-273. http:// dx.doi.org/10.1590/S0101-81751995000500001 